\title{
Entre a editorialização e a riqueza informativa: o papel dos implícitos no texto jornalístico informativo
}

\section{Between editorialization and informative richness: the role of the implicit in the informative journalistic text}

\section{Roberta Sartori Luso de Carvalho}

Doutora e mestre pela Pontíficia Universidade Católica do Rio Grande do Sul. Professora, orientadora de iniciação científica e de trabalhos de conclusão, coordenadora de Área de Linguagem e coordenadora do Núcleo de Idiomas e Cultura da ESPM-Sul, em Porto Alegre.

$<$ rsartori@espm.br>

\section{RESUMO}

\begin{abstract}
A identificação de conteúdos implícitos em textos jornalísticos do gênero informativo pode ser tratada como editorialização, expressão indevida e/ou escusa de conteúdos opinativos. O objetivo do artigo é mostrar que os textos do gênero informativo são constituídos a partir de vários e diferentes tipos desses conteúdos, gerados a partir da relação do uso da linguagem natural e de contextos específicos. A partir de um estudo bibliográfico e documental, avalia-se uma notícia, formato representativo do gênero informativo, e mostra-se que esses significados implícitos de fato têm um papel importante na construção da riqueza informacional e na constituição de uma textualidade eficiente dos textos, sem necessariamente caracterizar um processo de editorialização.
\end{abstract}

Palavras-chave: Gênero informativo. Editorialização. Significado implícito.

\begin{abstract}
The identification of implicit contents in the informative genre of journalistic texts may be treated as editorialization, the inappropriate and/or excuse expression of opinionative contents. The objective of this paper is to show that texts of the informative genre are built on many and different types of such meanings generated from the relation between the use of the natural language and specific contexts. From a bibliographic and documental study, it is assessed a piece of news, representative format of the informative genre, e it is shown that theses implicit meanings in fact play a very important role in the informational richness construction and in the constitution of an efficient textuality of the texts, no necessarily characterizing an editorialization process.
\end{abstract}

Keywords: Informative genre. Editorialization. Implicitmeaning.

\section{Introdução}

A caracterização, a função e as fronteiras dos gêneros informativo e opinativo ${ }^{1}$ é uma discussão permanente no jornalismo. Seria possível seguir a instrução de Martins (1997, p. 17): "faça textos imparciais e objetivos"; evitando conteúdos opinativos e a descaracterização do gênero informativo - dada a

\footnotetext{
1 Esforços para separar informação e opinião remontam à Alemanha do século 17, com Tobias Peucer, e à Inglaterra do século 18, com Samuel Buckely (Olson, apud Marques de Melo, 2011). Na esteira dessa tradição, mais contemporaneamente, encontramos Marques de Melo (2011) e Chaparro (2004).
} 
possibilidade de torná-lo um veículo para a transmissão legal ou ilegal, aberta ou escusa da opinião?

A discussão sobre textos de natureza informativa e opinativa passa necessariamente pelo seu conteúdo, o que nos compromete com o significado em linguagem natural. A escolha das formas de expressão empregadas pode mostrar explicitamente opiniões em textos opinativos, mas também pode veicular, através de conteúdos implícitos, opiniões em textos que, por hipótese, deveriam ser apenas informativos.

Quando considerados contextos comunicacionais particulares e o uso da linguagem natural para fins específicos, identifica-se o fenômeno da significação complexa: o dito semântico enriquecido com implícitos pragmáticos (Costa, 1984, 2016). Sartori $(1999,2015)$ tem defendido a importância de se distinguir o implícito enquanto fenômeno intrínseco da linguagem - recurso para enriquecimento informacional, organização da textualidade ${ }^{2}$ etc. - do implícito usado para a emissão de opinião. Daí propormos investigar a significação implícita, apresentando-a não necessariamente como evidência da inserção de opiniões em textos que deveriam se restringir à informação, ou seja, de editorialização (Douglas, 1966).

Para tanto, caracterizaremos os gêneros jornalísticos mencionados, apresentaremos os pressupostos teóricos assumidos e o papel da linguagem natural na e para tal discussão considerando as interfaces internas e externas dentro das quais o estudo será realizado, além das teorias linguísticas, comunicativo-sociais e lógico-cognitivas envolvidas. Procuraremos mostrar como implícitos em textos informativos não necessariamente configuram editorialização; mas sim um recurso próprio à natureza da linguagem e ao processo comunicacional que contribui para a riqueza informacional e eficiências textual e comunicacional; por fim, trataremos brevemente como,a partir da noção de intenção, é possível ler opiniões onde elas não necessariamente estão.

\section{Os gêneros informativo e opinativo}

A base do jornalismo é a informação sobre a realidade social imediata (Bahia, 1990) que tem papel importante na vida dos leitores (Keeble, 2001). Não fosse assim, o jornalismo poderia não se distinguir da literatura ou da história, por exemplo. Tal gênero, o primeiro a figurar na imprensa mundial (Marques de Melo, 2003; Assis, 2010), tinha como função única, por hipótese, apresentar, descrever uma sucessão precisa dos fatos (Peucer,

2 Silveira e Feltes (2002) estudaram a textualidade à luz de teorias inferencialistas. 
2000; Marques de Melo, 2003), de forma neutra, objetiva (Assis, 2010), e com um distanciamento "passivo dos eventos que trata" (Kunczik, 2002, p. 97).

A notícia, formato clássico do gênero informativo, não consiste, contudo, "na perfeita tradução dos fatos, ela não é uma ocorrência, mas a história desse acontecimento" (Menna Barreto, 2003, p. 79), e a linguagem da notícia não é uma forma natural e espontânea de escrita, mas um discurso com ritmo, entonação, palavras e orações próprias (Keeble, 2001). Essa forma de apresentação dos fatos, e construção (linguística) do texto, sustenta-se sobre três pilares: veracidade, imparcialidade e objetividade.

Suzuki $^{3}$ (1999, p. 65, grifo nosso) destaca que a veracidade consiste na exatidão, propriedade relativa à escolha vocabular: "a palavra adequada é sempre a palavra justa, sem valores intrínsecos e diversos significados". Para Hicks $^{4}$ (1999, p. 66, grifo nosso, acréscimo nosso), a "precisão e a efetividade na redação [jornalística] dependem de um uso adequado da linguagem. [Devese] aprender a reconhecer as palavras e locuções que irão veicular seu significado de forma exata e vívida ao leitor". Independentemente do idioma em que escrevem e sobre o qual refletem a redação do texto jornalístico ${ }^{5}$, os autores parecem acreditar em uma espécie de emparelhamento entre a palavra e a coisa. A crença na noção de um significado literal e de uma relação unívoca entre palavra e referente possibilitaria a construção de textos genuinamente informativos, que permitissem e promovessem também interpretações únicas - como se emanassem da codificação/decodificação do texto.

Há quem defenda que, no máximo, pode-se ser "o mais objetivo possível" (MANUAL..., 2008, p. 46). Nessa visão, "as tomadas de decisões que regem o trabalho do jornalista são 'medidas subjetivas"' (Assis, 2010, p. 19). Entendemos, contudo, que, nessa discussão, é um salto muito perigoso emparelhar a necessidade de recorte dos fatos e a expressão dos mesmos, em especial, quanto às escolhas vocabulares e às estratégias textuais, como reflexo necessário da impossibilidade da objetividade.

Embora o gênero informativo seja o mais importante, Marques de Melo (2006b, citado por Assis, 2010, p. 20) lembra que o gênero opinativo é "o segundo predominante na esfera jornalística", atendendo, conforme Assis (2010, p. 21), "bem mais do que à necessidade humana de se expressar: ele também subsidia, em larga medida, a formação da opinião pública". Apesar da

3 Existe uma grande gama de propriedades. Para uma discussão mais detalhada, ver Sartori (1999).

4 Trouxemos teóricos que discutem a construção do texto em português e em inglês, pois pretendemos mostrar a generalidade das reflexões aqui propostas.

5 Suzuki fala sobre o texto em língua portuguesa; Hicks, sobre o texto em língua inglesa. 
importância da opinião, a história do jornalismo é marcada por esforços dos jornais para exorcizá-la das suas páginas. Um deles foi a criação de espaços especiais para sua manifestação, como o editorial, o artigo de opinião, por exemplo (Assis, 2010). O texto perdeu sua acepção idealista para um caráter mais concreto, privilegiando-se, cada vez mais, a função referencial da linguagem que caracteriza a chamada de retórica da notícia -, em detrimento das funções poética, expressiva e apelativa - conforme definidas por Jakobson (2007).

O perigo da opinião no texto jornalístico de natureza informativa foi identificado por Douglas (1966) como editorialização; segundo ele, o mais grave defeito que um título, até mesmo o texto, pode apresentar. Mesmo reconhecendo que, "sem nenhuma exceção, a opinião do jornal ou do redator somente pode ser divulgada no confinamento inequívoco da página dos editoriais" (Douglas, 1966, p. 30, grifo nosso); o autor assume que nem sempre é fácil identificar a diferença entre caracterização do fato e a sua editorialização.

Embora seja possível identificar certa sobreposição entre os gêneros, afinal, só se pode opinar sobre fatos e ideias, é exagerado dizer que não seja possível informar sem emitir opinião. Autores como Lustosa (1996) não aceitam que haja imparcialidade na linguagem, afirmando que $o$ jornalista é parcial até mesmo ao escolher o melhor ângulo para descrever e apresentar os fatos. Reduzir tudo a ideologias e à subjetividade, como fazem certas abordagens mais tradicionais da Análise do Discurso, consideramos excessivo. Tratar cada escolha vocabular como subjetividade é um exagero. Acreditamos que essa escolha não seja tão subjetiva assim, mas que ela também é orientada por aspectos que o jornalista assume a respeito do seu leitor, aspecto melhor abordado a partir de uma abordagem de interfaces.

Nesse jogo da relação entre o jornalista e o seu público, é importante ressaltar que em todos os manuais tal comunicação é assumida pela Teoria de Códigos. E nada se fala sobre significado implícito, que possui um papel crucial na comunicação. Ainda seilustra um modelo de comunicação em que a mensagem entra na cabeça do ouvinte sem nenhuma alteração de seu conhecimento de mundo, do contexto em quealinguagemestáenvolvida(MennaBarreto,2003,p.82,grifonosso).

Menna Barreto (2003) defende, portanto, que os estudos tradicionais do jornalismo não contemplam uma comunicação cooperativa entre jornal e leitor - e que o implícito deve ser contemplado como parte dessa abordagem na qual ele tem desempenha papel na comunicação enquanto fenômeno, não necessariamente enquanto conteúdo editorializado. 
Procuraremos mostrar que, muitas vezes, certas escolhas e estratégias linguísticas consistem em um emprego otimizado de recursos intrínsecos à natureza da linguagem natural para uma comunicação eficiente, justamente devido a essa nova forma de entender a comunicação, de forma geral, e o fenômeno da significação em linguagem natural, de forma específica.

\section{Comunicação, metateoria das interfaces e abordagens inferenciais}

Apresentaremos aqui os aspectos metateóricos e teóricos que sustentam e viabilizam uma alternativa para o tratamento da significação complexa em linguagem natural, os quais podem auxiliar na investigação aqui proposta sobre o texto informativo. Pretende-se sugerir, a partir da identificação da riqueza e dos diferentes tipos de conteúdos extraliterais, que a presença desses implícitos não necessariamente caracteriza a editorialização: veiculação escusa de conteúdos cuja transmissão não se quer/não se pode assumir.

A significação em linguagem natural, especialmente em situações de uso, consiste em um fenômeno com diferentes propriedades (Costa, 2008). Pela Metateoria das Interfaces Internas e Externas, Costa (2007) sugere que tais fenômenos sejam construídos como objetos complexos e tomados como generalizações que envolvem diferentes disciplinas. Neste caso, consideram-se aspectos referentes à dependência contextual e às perspectivas social, cognitiva e lógica, em situação interdisciplinar.

Assim, as interfaces externas, local das explicações, são constituídas pela Linguística (interessando o processo inferencial em linguagem natural), Cognição/Lógica (assumindo-se um modelo de processamento cognitivo com base em princípios da Lógica) e a Comunicação (assumindo-se um modelo comunicacional). As interfaces internas, local das descrições, são a semântica e a pragmática. As teorias adotadas são a Teoria das Implicaturas/TIG (Grice, 1991), a Teoria da Relevância/TR (Sperber; Wilson, 1995) e a Teoria das Implicaturas Conversacionais Generalizadas/TICG (Levinson, 2000). Por terem caráter inferencialista, contemplarem a racionalidade e a linguagem natural, os modelos podem ser articulados e permitem a descrição de diferentes tipos de enriquecimento informacional a partir do dito - os quais contribuem para a configuração do texto e eficiência da veiculação de informações.

ATIG (Grice, 1991) lançou nova luz sobre a comunicação verbal, tratando-a a partir das noções de intenção e inferência6; não mais como um processo

6 Trataremos a noção de inferência conforme Costa (2007): em sentido amplo (pragmático) como sinônimo de raciocínio. 
de codificação e decodificação, conforme o tradicional Modelo de Códigos (Shannon;Weaver, 1949). Além do significado convencional das palavras, aspecto semântico, o dito, também o implicado, aspecto pragmático, o que o emissor quis dizer com o que disse, contribui para a elaboração e compreensão de mensagens.

O dito é a evidência oferecida pelo emissor ao interlocutor para que sua intenção seja identificada, via um processamento inferencial, resultando no implicado (Grice, 1991). Em Grice (1991), o dito consiste no significado convencional de uma proposição. Tudo o que está para além dele, excetuando-se a atribuição de referência e a desambiguação, é implicatura. Compreender é, portanto, capturar inferencialmente o que está para além da decodificação linguística do dito. Há, contudo, diferentes tipos de implicaturas.

As convencionais dependem do significado convencional das palavras. $\mathrm{O}$ significado de um enunciado nãoé determinado somente pelo queéliteralmente expresso, mas também pelo que é convencionalmente implicado. Em 'O texto é uma notícia, mas tem opiniões', está dito que 'o texto é uma notícia' e que 'o texto tem opiniões', mas não está dito que'textos que são notícias não devem ter opiniões'-embora possa ser inferencialmente depreendido pela conjunção'mas'.

As implicaturas conversacionais são de dois tipos. As generalizadas independem de contexto particular (Grice, 1991). Ao dizer, 'Há um jornal em cima da mesa', o falante implica que aquele exemplar não é seu. As implicaturas particularizadas são originadas a partir (i) de contextos específicos e (ii) da forma como o emissor produz o enunciado - tendo em vista as máximas conversacionais que constituem o Princípio de Cooperação (PC): Faça sua contribuição conversacional da maneira como ela é exigida, no estágio em que a conversa se encontra, segundo o propósito ou direção aceitos (Grice, 1991). O PC e as máximas identificam implícitos que completam pragmaticamente o sentido do dito. $O$ papel das máximas é especificar 0 que os interlocutores têm que fazer para conversarem de forma cooperativa, racional e maximamente eficiente: devem falar sincera [Categoria da Qualidade], relevante [Categoria da Relação] e claramente [Categoria de Modo], fornecendo informações suficientes [Categoria da Quantidade] (Levinson, 1983, acréscimo nosso). As implicaturas seriam geradas pela forma como as máximas são tratadas: (i) nenhuma é violada, (ii) uma é violada para que outra não seja, (iii) uma é propositalmente violada para a geração de uma implicatura. Grice (1991) identificou algumas propriedades para as implicaturas particularizadas. Devem ser fruto de um cálculo feito pelo ouvinte a partir do significado literal, do PC e das máximas. Devem poder ser canceladas: 'A tiragem daquela edição foi de 200 mil exemplares, se não mais'. $O$ acréscimo de 'se não mais' cancela a implicatura 'A tiragem foi de apenas 200 mil 
exemplares ${ }^{\prime 7}$. E serem indetermináveis, uma expressão, aparentemente com um significado único, pode gerar diferentes implicaturas, cuja depreensão exata pode ser difícil, por ser vaga ou imprecisa: o cálculo da implicatura pode levar a uma espécie de lista aberta de conteúdos. Dado um diálogo entre (A), (B) e (C): “(A) - 'Que tal nosso editor-chefe?'; (B) - 'Novo demais.'; (C) - 'Cheira a leite ${ }^{8}$.', (B) pode querer implicar que o editor-chefe é muito jovem, muito inovador ao tomar decisões, etc. A resposta de (C) ilustra metáforas; o falante pode querer implicar, assim como (B), que o editor-chefe é muito jovem, mas poderia estar fazendo referência à sua experiência profissional ${ }^{9}$.

A TR, de Sperber e Wilson (1995), é uma releitura cognitiva da proposta inferencial da TIG. Alicerçados na cognição e na lógica, em interface com a comunicação, os autores propõem o princípio da relevância como uma propriedade da cognição humana: os seres humanos têm a tendência a prestar atenção àquilo que Ihes parece relevante, aspecto que dispara os processamentos inferenciais (Sperber; Wilson, 1995). A relevância consiste na relação entre o custo cognitivo de processamento de uma informação e o efeito obtido - numa relação entre economia e eficiência.

Pela TR, duas propriedades jamais podem estar dissociadas na comunicação: (i) a ostensão, por parte do emissor, através do que ele manifesta sua intenção informativa, a de tornar manifesto um conjunto de suposições; e a comunicativa, a de tornar mutuamente manifesto ${ }^{10}$ esse conjunto de suposições; e (ii) a inferência, realizada pelo receptor, processo em que ele constrói o contexto que lhe permite chegar à interpretação pretendida pelo emissor. A TR caracteriza-se como uma abordagem pragmático-lógico-cognitiva do processamento inferencial da comunicação.

Dois princípios regem esse processamento. O Princípio Cognitivo diz que "a comunicação humana tende a ser dirigida pela maximização da relevância" (Sperber; Wilson, 1995, p. 260). Não há garantia de que as pessoas sempre alcançarão relevância ótima em todos os processamentos inferenciais executados, apenas quea mente humana procura escolher os melhores estímulos

\footnotetext{
7 O cancelamento visa à manutenção do PC.

8 Adaptado de Sartori (1999).

9 (B), portanto, viola a primeira máxima da quantidade (Faça a sua contribuição tão informativa quanto o exigido para o propósito da conversação), oferecendo menos informação do que o necessário para a conversação; (C) parece violar a primeira máxima da qualidade (Não diga o que considerar falso) - tudo visando à manutenção do PC, pois o ouvinte se vê autorizado a buscar os implícitos que complementarão os ditos, acomodando-os à situação comunicativa em curso. 10 Caso em que o emissor e o receptor podem representar tais suposições - ambos as compartilham.
} 
ostensivos (inputs), ativar o conjunto de informações ${ }^{11}$ mais relevantes (as suposições mais facilmente acessadas ${ }^{12}$ ) para aqueles estímulos e processá-los da forma mais produtiva (a que gera mais efeitos cognitivos pelo menor esforço) - tendo em vista a intenção do comunicador. Pelo Princípio Comunicativo, "todo estímulo ostensivo comunica a presunção de sua relevância ótima" (Sperber; Wilson, 1995, p. 260). Um estímulo é otimamente relevante se, e somente se, (i) for relevante o suficiente para merecer o esforço de processamento do receptor e (ii) for o mais relevante tendo em vista as habilidades e preferências do emissor. Um estímulo é considerado relevante desde que o esforço compense seu processamento: seja por efeitos elevados, seja por baixo esforço de processamento. Se demandar mais custo, será relevante se gerar mais benefícios.

A noção de esforço está ligada à releitura cognitiva da noção de contexto - o qual não é mais assumido como pré-conhecido ou pré-estabelecido, mas construído on-line, no momento da troca comunicacional, constituindo um conjunto de premissas ${ }^{13}$ usadas pelo receptor para interpretar um estímulo. As suposições que formam o contexto podem ser oriundas de diferentes fontes: da percepção sensorial, da decodificação linguística (lida ou ouvida), da dedução e dos esquemas de suposições armazenados na memória dos indivíduos.

Os efeitos cognitivos atuam sobre o conjunto de crenças/suposições que as pessoas entretêm sobre o mundo, as quais podem ser, a partir de novas evidências, fortalecidas ou contraditas, o que pode levar desde ao enfraquecimento até o apagamento dessas ou de outras suposições. As suposições acrescidas são as implicações contextuais ${ }^{14}$; segundo a TR, fruto da informação nova $(P)$ processada em $(C)$. Ao fundamentar-se na lógica, a TR explica a capacidade do ser humano para identificar conflitos entre as suposições que já tem representadas e aquelas que recebe como input.

ATR trata o dito como um conceito mais complexo na interface semânticopragmática, através da noção de explicatura. O conteúdo explícito/dito (ou forma lógica), não é mais apenas o significado convencional das expressões; antes de gerar os implícitos, ele é enriquecido por informações de natureza pragmática, envolvendo uma série de processos até a obtenção da explicatura (Sperber;

11 Para Sperber e Wilson (1995), as entradas de informação são: enciclopédica (informações armazenadas na memória dos indivíduos), lógica e verbal.

12 Dependendo da acessibilidade das informações, elas podem ser consideradas como sendo fortemente implicadas, claramente pretendidas, e fracamente implicadas, menos pretendidas, e suposições não comunicadas, ou seja, não manifestas (Sperber; Wilson, 1995).

13 Esse conjunto é um subconjunto das crenças, suposições armazenadas na memória enciclopédica, que o receptor tem sobre o mundo.

14 Elas são, por excelência, os efeitos cognitivos, segundo os autores, que mais atuam para o aprimoramento do ambiente cognitivo das pessoas (representação de mundo que as pessoas têm armazenada). 
Wilson, 1995). Além da desambiguação e da atribuição de referência griceanas, na TR, fazem parte do dito o preenchimento de elipses, a interpretação de expressões vagas, a determinação de atitudes ilocutórias (atitude proposicional do falante em relação à elocução proferida). Para Sperber e Wilson (1995), os processos que levam às interpretações são realizados online e ajustados em paralelo ${ }^{15}$.

Embora Grice (1991) tenha pouco desenvolvido as implicaturas conversacionais generalizadas, Levinson (2000) assume que há espaço para elas. Esses implícitos constituem um nível intermediário entre a interpretação convencional semântica (o dito) e a ocorrência específica pragmática (o implicado), caracterizando uma espécie de interpretação default/preferida - independente de contexto específico. Do enunciado 'Alguns redatores são objetivos' depreende-se que 'Nem todos os redatores são objetivos'. Segundo Levinson (2000), trata-se de uma ICG, pois ela não pode ser reduzida ao significado do termo 'alguns', daí ser tomada como inferência pragmática: cancelável e não necessária. Levinson (2000) identificou três heurísticas, a partir de máximas de Grice relacionadas à forma de se dizer algo.

Pela Heurística Q, "O que não é dito não é”, o emissor deve dizer tudo o que pode, contanto que permaneça dizendo a verdade. Pela Heurística I, "O que é simplesmente descrito, é estereotipicamente exemplificado": o que pode ser tomado como sendo o caso, não precisa ser enunciado. Pela Heurística $\mathrm{M} .^{16}{ }^{16}$ "O que é dito de forma anormal, não é normal": o emprego de uma forma não usual para dizer algo significa que situação é não usual.

Grice propôs a TIG como um modelo alternativo ao de Códigos, mas Sperber e Wilson (1995) aliaram o processo de codificação/decodificação ao reconhecimento inferencial de intenções, tratando-os como procedimentos complementares da comunicação, agora à luz do processamento cognitivo de propriedades lógicas. Levinson (2000) estendeu o tratamento daquelas inferências, embora canceláveis, específicas aos hábitos do emprego da linguagem que não envolvem contextos particulares, ampliando a identificação e possibilidade descritiva de fenômenos linguísticos. ATR, portanto, fortalece as explicações sobre como e porque as pessoas interagem e se compreendem - e como a comunicação atua nos indivíduos -, enquanto a TIG e a TICG, e também a TR, auxiliam na identificação dos tipos de implícitos e dos níveis de interpretação.

15 Ou seja, conforme a troca vai sendo realizada.

16 Está diretamente associada à máxima de Modo griceana (seja claro, evite obscuridade de expressão, ambiguidade, seja ordenado). 


\section{Análise ilustrativa}

Embora a TR trate preferencialmente da comunicação oral, Silveira e Feltes (2002, p. 64) argumentam que é possível aplicar o modelo à comunicação escrita:

Se, conforme Sperber e Wilson, o papel do ouvinte é tão importante nesse processo [comunicativo], e se o comportamento verbal dos falantes é restringido pela expectativa de Relevância do ouvinte, então, em termos de autor e leitor, tal expectativa deve ser [igualmente] considerada a base para a análise do texto/discurso.

Campos (2009) ratifica essa perspectiva ao reconhecer que "ler consiste, essencialmente, num processo de construir cognitivamente uma espécie de código mental a partir de um código escrito [...] ler não é adivinhar, é decodificare compreender" (Campos, 2009, p. 58-59, grifo nosso). Assim, se compreender um texto escrito consiste também na capacidade de produzir inferências relevantes, envolvendo o menor custo de processamento para mais efeitos cognitivos, então:

textos e títulos jornalísticos podem ser igualmente tratados a partir de inferências, especialmente porque, como Silveira e Feltes (1997) tão bem mostraram, a textualidade que igualmente caracteriza a lógica dos textos jornalísticos não se constrói apenas a partir dos elementos coesivos codificados (Sartori, 2015, p. 59-60).

Silveira e Feltes (2002) propõem o tratamento da textualidade à luz das relações de relevância. Para as autoras, os mecanismos de coesão são mais do que meros marcadores de coerência, funcionam como marcas empregadas pelo escritor para a boa formação textual e para orientar o leitor na interpretação desejada.

Acreditamos que essa construção textual inferencial e a crença, por parte do jornalista, nessa capacidade do leitor de seguir essas pistas sejam fundamentais na elaboração de textos que envolvam implícitos, os quais colaboram para que o texto possa veicular muito mais significados do que aqueles codificados, permitindo, como Menna Barreto (2003) sugere, que esses conteúdos sejam complementares ao texto; sem que caracterizem a editorialização apenas por não estarem codificados.

A notícia usada para ilustrar os aspectos discutidos foi publicada pelo jornal Zero Hora, em 31 de agosto de 2015, p. 16. Embora narre o fato a respeito 
de migrantes sírios terem sido encontrados em um caminhão, tentando entrar na Europa pela Áustria, o nosso foco recai sobre o que aconteceu com as crianças que estavam com o grupo. Não analisaremos a notícia na íntegra. Interessamnos o antetítulo, o título, o subtítulo e os seis primeiros parágrafos ${ }^{17}$.

\section{Figura 1 - Trecho da notícia analisada}

\section{MUNDO | CRISE DE MIGRAWTES}

\section{Crianças sírias somem de hospital na Áustria}

DUAS MENINAS E UM MENINO tinham sido

localizados com os pais em "estado precário"

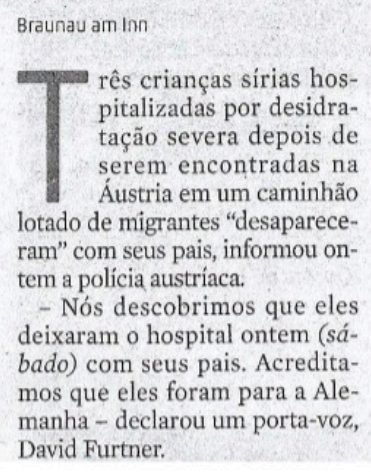

As duas meninas de cinco e seis anos de idade e um menino de seis anos estavam com um grupo de 26 migrantes descobertos na sexta-feira pela polícia na traseira de um caminhão, perto da frontëira com a Alemanha.

A descoberta ocorreu depois de

71 corpos de migrantes serem encontrados na quinta-feira passada em um outro caminhão abandonado em uma rodovia austríaca.
As três crianças foram hospitalizadas "em estado extremamente precário" de saúde. A agência de notícias austríaca APA citou ontem um médico do hospital da cidade de Braunau am Inn que afirmou que mesmo se as crianças fossem mantidas no estabelecimento como o esperado "já não estavam em perigo do ponto de vista médico".

Vejamos implícitos relacionados ao enriquecimento ${ }^{18}$ do dito, responsáveis pelo aumento/especificação da carga informacional das mensagens codificadas. Ao contrário do que sugerem Suzuki e Hicks, não há como se ter a palavra exata - mas isso não significa que a compreensão seja prejudicada ou que a clareza e a objetividades sejam anuladas. Segundo Levinson (2000), isso pode ser alcançado por uma restrição da interpretação para um termo, só daí é possível identificar, inferencialmente, de forma mais exata, o que o jornalista está querendo dizer com o que disse.

O uso do termo'crianças' no título não é tão exato quanto parece à primeira vista. Embora se possa aplicar o sentido de 'bebês' para o termo 'crianças', esse não parece ser o caso, a interpretação default para 'crianças' parece não englobar preferencial e estereotipicamente o sentido'bebê'. Segundo Levinson (2000), isso ocorre por uma IGC-Q - quando a afirmação de um termo mais baixo em uma

17 São esses os parágrafos que tratam especificamente do que ocorreu com as crianças, os demais tratam da crise dos refugiados em geral.

18 Paradoxalmente, esse aumento informacional consiste na restrição mais exata daquilo que um termo de fato significa. 
escala implica a negação do mais alto. Assim, em uma escala $<$ bebê, criança ${ }^{19}$, afirmar'criança' implica'não bebê'. Tanto isso parece ser verdade que, se tivessem sido encontrados bebês, e o jornalista tivesse mantido o termo 'crianças', pode-se dizer que ele não teria sido tão preciso, tão exato quanto deveria.

Nos termos de Grice, o jornalista teria violado o PC, ao ser menos informativo do que o exigido ou do que poderia/deveria ser. Essa interpretação default parece se confirmar mais adiante na notícia: há trechos que reforçam a implicatura não bebê. No terceiro parágrafo, o jornalista, para retomar 'crianças', escreve "as duas meninas de cinco anos de idade o um menino de seis anos [...]". Nesse momento, estabelece-se outro tipo de implícito, agora uma IGC-I, através do qual oleitor infere que ojornalista está se referindo às crianças mencionadas no título. Constrói-se, assim, a textualidade, a coesão do texto - de forma inferencial.

Outro conteúdo não codificado, mas obtido por implicatura, vem do verbo 'acreditar' em "[...] 'Acreditamos que eles foram para a Alemanha' [...]". Em uma escala <saber, acreditar>, o uso de 'acreditar'implica 'não saber': apesar de 'saber' estar também disponível, ao usar 'acreditar', o emissor implica não poder afirmar a expressão mais forte, não pode afirmar que sabe algo com certeza. Esses implícitos têm outro papel importante, agora de natureza mais prática.

Por essa ICG-Q, o falante não precisou codificar algo como ‘não podemos afirmar com certeza etc..' Dada a limitação de espaço nos jornais impressos, o verbo 'acreditar', por desencadear essa implicatura, economiza caracteres digitados. Para escrever "não podemos afirmar com certeza" são necessários, com espaços, 31 caracteres; para escrever "acreditamos" são necessários, com espaços, apenas 11 caracteres.

Pela Heurística M, expressões marcadas disparam implicaturas sinalizando um propósito especial para seu emprego - a forma, mais do que o significado da expressão, orienta a interpretação. São usadas duas formas diferentes para fazer referência aos os dois grupos de migrantes mencionados na notícia, os quais foram encontrados em situações semelhantes: "um grupo de 26 migrantes" e "71 corpos de migrantes". Por uma ICG-M, da expressão 'corpos', infere-se, sem ser preciso codificar, que aspessoas estavam mortas. Da expressão 'grupo', essa inferência não tem motivação alguma; pelo contrário, por uma IGC-I, pela Heurística I, a interpretação preferida é a de que as pessoas estavam vivas.

Outro tipo de implícito que está associado à economia linguística e à textualidade, e, portanto, à eficiência comunicacional do texto, e que não tem

19 Qualquer conjunto de expressões pode constituir uma escala, mas deve existir qualquer relação de ordenação definida sobre elas, em modo contextualmente saliente (Levinson, 2000). 
necessariamente nada a ver com editorialização, pode ser verificado no seguinte trecho literal da notícia em (1a) - e sua contraparte em (1b).

(1a) As duas meninas de cinco e seis anos de idade e um menino de seis anos estavam com um grupo de 26 migrantes descobertos na sexta-feira.

(1b) As duas meninas de cinco [anos de idade] e seis anos de idade e um menino de seis anos [de idade] estavam com um grupo de 26 migrantes [que foram] descobertos na sexta-feira [28 de agosto de 2015 $]^{20}$.

Podemos verificar que os vários termos, e conteúdos, entre colchetes, puderam ser deixados elípticos. Segundo Levinson, por serem interpretações default, essas relações não precisam estar codificadas, pois podem ser facilmente inferidas pelos leitores. Caso fossem codificadas, por relevância, sua decodificação e compreensão só gerariam custo, sem benefício agregado - e a sua não codificação não gera problemas de compreensão.

Da configuração do subtítulo, "duas meninas e um menino tinham sido localizados com os pais em 'estado precário'", pode-se obter mais de uma interpretação: (i) somente as crianças estavam em estado precário, (ii) os pais estavam em estado precário, e (iii) todos estavam em estado precário. Aqui há uma evidente quebra da máxima griceana de modo, evita ambiguidade. Essa ambiguidade, entretanto, poderia até gerar uma quebra do PC, não fosse o tipo de texto no qual ela é empregada. O subtítulo tem como algumas de suas funções reforçar a intenção do título, somar informações, especificar informações já apresentadas etc. O subtítulo em questão especifica o título: o termo 'crianças' é retomado e especificado através da expressão 'duas meninas e um menino'. Tendo em vista o PC e a proposta de interpretação default, o estabelecimento da coesão, também assumido pela TR como sendo inferencial, consiste na suposição de que as meninas e o menino são as crianças referidas no título. Há outras pistas que reforçam isso: o fato de se afirmar que estavam em estado precário e de se dizer por que as crianças estavam no hospital do qual sumiram.

Dado o título, por relevância, agora a partir de contexto particular, a interpretação melhor candidata seria a primeira, somente as crianças estariam em estado precário. Entretanto, pelas informações dotexto, dado que os pais também

20 Costa (2012), na Teoria do Diálogo, sugere que as inferências, especialmente aquelas relacionadas às ICGs, deixam o dito mais econômico. Daí ele fazer a distinção entre o dito explícito (1a) e o que corresponderia ao dito implícito (1b). 
foram encontrados no caminhão, pode-se inferir que eles também estavam em estado precário. Por essa breve análise, não se pode dizer que o jornalista, ao escrever o subtítulo, tenha sido o mais cooperativo possível; pela TR exige-se do leitor um esforço a mais, pois há três possibilidades interpretativas, esforço esse que não traz nenhum benefício extra, uma vez que o esforço depreendido até o momento é para resolver a ambiguidade. A beleza da articulação dos modelos é que, embora Levinson fale em conhecimento de mundo, ele não traz a cognição como explicação de como empregamos esse conhecimento. Ao articularmos sua proposta com a TR, temos embasamento explanatório na cognição humana para explicar de onde vem esse conhecimento de mundo e linguístico, além do default, e como se fazem esses ajustes interpretativos online.

Outro exemplo que desafia a noção de precisão, mas permite descrever e explicar como compreendemos o texto vem da expressão 'precário'. Dada uma escala <grave, correndo risco, precário $>$, por implicatura $Q$, do emprego da forma mais baixa na escala, é possível inferir a negação da mais alta, daínão grave' ou 'não correndo risco'. A prova de que estamos tratando de inferências canceláveis, é que, embora essa interpretação enfraqueça quando o jornalista, mais adiante, no quinto parágrafo, escreve 'extremamente precário', ainda não se chega à interpretação 'grave', 'correndo risco', e, se se chega a ela, ela é cancelada, pois as crianças deixaram o hospital e, mesmo sem a autorização dos médicos, um deles declara que as crianças "já não estavam em perigo do ponto de vista médico". Na verdade, não se tem, de forma mais exata, ao menos não positivamente falando, uma ideia de qual era o estado das crianças. Entretanto, pode-se ter uma ideia mínima necessária para a compreensão da notícia: ruim o suficiente para serem hospitalizadas, não tão ruim para saírem, sem recuperação completa e, ainda assim, não correrem risco.

Como foi possível observar, a suposição desses tipos de implícitos, como fenômeno característico da linguagem natural, e complementar ao texto, permite que se tenha no texto jornalístico, mesmo que aparentemente não se perceba, representações semânticas, ditos, de certa forma, fragmentados. Alguém poderia dizer que o jornalista está sendo contraditório ao falar a respeito do estado das crianças, mas, agora, a partir da dinamicidade de um modelo com base na cognição e na lógica, podemos ilustrar outros tipos de implícitos e justificar por que o texto pode ser escrito, por exemplo, não exatamente na ordem linear em que os fatos ocorreram.

Segundo a TR, para ser relevante, o emissor deve fazer algumas suposições a respeito das habilidades cognitivas e dos recursos contextuais do receptor. No caso do jornalismo, deve-se levar em consideração inclusive o espaço que terá disponível. Assim, o jornalista deve prever a linguagem que poderá usar, o que o 
receptor já deve saber ou já sabe, etc. Esses aspectos se refletem nas escolhas que ele [emissor] fará para se comunicar, especialmente no que diz respeito àquilo que escolhe deixar explícito e o que escolhe deixar implícito (Sperber; Wilson, 1995).

É nesse sentido que discordamos da afirmação de que as decisões do jornalista sejam puramente subjetivas no sentido mais ideológico ou meramente individualista do termo. No mínimo, ao prever os aspectos levantados, pode ser considerada, no mínimo, uma decisão a dois. Não descartamos a subjetividade mais intimista e com uma agenda mais particular, apenas acreditamos que imparcialidade não é uma utopia.

Agora uma aplicação mais objetiva do processamento envolvendo a TR. Comecemos pela página onde está o texto, na qual o termo 'notícias' está visualmente posicionado antes dos demais elementos e da própria notícia - em local de destaque. Nessas condições, pela TR,'notícias', que consiste em um input visual, caracteriza-se por ser uma entrada lexical que orienta quais informações enciclopédicas devem ser recuperadas, bem como de que forma as informações que se seguem devem ser interpretadas. Esse input está localizado de tal forma a chamar a atenção do leitor, apresentando-se como relevante.

Por estar em uma página de um jornal, ele serve como input visual que resgata também informações enciclopédicas sobre o jornalismo. Isso significa que as informações apresentadas devem ser tratadas como verdadeiras e recentes, propriedades do gênero jornalístico ao qual pertence o formato notícia. Esse aspecto é o primeiro conjunto de suposições dentro do qual o restante do texto será compreendido.

Sob o escopo do termo 'notícias', aparecem, no antetítulo, os termos 'mundo' e 'crise dos migrantes' - posicionados antes do título e da notícia propriamente ditos. Esses elementos igualmente consistem em estímulos ostensivos visuais tipo entradas lexicais - intencional e mutuamente manifestos para o leitor. A partir deles, os leitores acessam informações da sua memória enciclopédica a fim de construírem o contexto em que as informações deverão ser interpretadas.

A entrada lexical 'crise', completada pela outra entrada lexical 'de migrantes', permite inferir que a crise se refere às dificuldades enfrentadas por pessoas que saem de seus locais de origem. A entrada lexical 'mundo' auxilia o leitor a inferir que a notícia não será sobre qualquer tipo de migrantes. Note-se que as palavras do antetítulo caracterizam-se, à primeira vista, por uma séria quebra da máxima griceana, especialmente a da quantidade, no que diz respeito ao fornecimento de informações suficientes, e a de modo. Em Grice, isso significa que ou o PC foi violado ou, para isso não acontecer, o leitor estaria autorizado a preencher inferencialmente essas lacunas, afinal, não 
estaria supondo que o jornalista quebrou o PC. Contudo, pela TR, explica-se cognitivamente a possibilidade para tanto - tratando essa forma de escrever, nesse contexto, como desejável e perfeitamente plausível. Esse subtítulo se caracteriza por uma forma lógica que será completada por relevância até formar uma explicatura, a partir da qual, as derivações irão ocorrer - sem que isso exija esforço extra de decodificação.

Dado que os conflitos no Oriente Médio estão, a todo momento, sendo noticiados - em jornais, rádios, TV e internet -, o jornalista pode supor que o leitor não terá dificuldades para acessar tais informações. Estamos ainda no momento em que, inferencialmente, se está recuperando informações - ou seja, selecionando o contexto no qual a informação nova, anunciada pelo título deverá ser interpretada. Antes ainda das derivações, da geração dos efeitos cognitivos, há outro processo inferencial que é realizado pelo leitor. Ele levanta possíveis hipóteses interpretativas. Iremos verificar esse aspecto tratando especificamente do título.

Levando em consideração o aspecto puramente semântico do título, 'Crianças sírias somem de hospital na Áustria', ele é vago; há, portanto, várias hipóteses interpretativas. Inicialmente, seriam recuperadas as interpretações default. Assim, 'sumir' pode significar que as crianças foram levadas por alguém ou que, dependendo da idade, elas fugiram. Se elas sumiram de um hospital, por interpretação preferida, IGC-I, por uma restrição de generalidade, infere-se que elas estavam internadas - pela TR essa seria interpretação ótima - menos esforço para maior benefício.

Dado que as crianças são sírias e que o hospital fica na Áustria, isso significa que elas, enquanto migrantes, oriundas de um país em séria e violenta guerra, ou vieram machucadas ou algo aconteceu ao longo do caminho percorrido na condição de refugiados. Verifica-se a importância dos estímulos ostensivos: dentro do contexto da crise dos migrantes, esses inputs visuais, especialmente escolhidos pelo emissor, funcionam como pistas, no caso entradas lexicais, a partir das quais informações podem ser recuperadas.

O subtítulo é outro exemplo de estímulo ostensivo que desencadeia uma série de processamentos inferenciais. Como ele deve ser um texto que resume a notícia, muito acaba ficando ou por ser restringido pela notícia ou por ser confirmado por ela - no caso, as duas coisas, acontecem com esse subtítulo. Há uma lacuna na frase a respeito de onde as crianças foram localizadas, mas é dito que estavam em estado precário. Seja como for, a expectativa é a de que seja um local não apropriado, perigoso. Mais adiante, a informação codificada de que esse local é um caminhão, e que ele está lotado de migrantes, não apenas especifica e preenche a lacuna, por decodificação, como, por inferência, corrobora que o 
lugar, de forma alguma, é minimamente apropriado para pessoas, muito menos crianças. Mais uma vez, inputs visuais, na forma de entradas lexicais, são tornados mutuamente manifestos para dar início a outro processamento inferencial de recuperação de informações através do acionamento do conhecimento enciclopédico do leitor.

Segundo Sperber e Wilson (1995), esses processamentos se dão em paralelo; mas, para fins da análise usaremos um caminho. $O$ primeiro input poderia ser 'caminhão'. Embora seja um meio de transporte, ele não é adequado para transportar seres humanos - aqui a melhor forma de entender o termo é que ele é usado pelos seres humanos para se deslocarem tendo em vista o transporte de coisas. Vemos o cancelamento de uma inferência que seria default ea busca de outra, que, embora exija mais esforço, trazmais benefícios cognitivos.

O fato de o emissor ter usado a locução verbal na voz passiva 'serem encontrados' permite que se levante a hipótese de que as pessoas estavam escondidas, e que o que faziam era algo que não se pode fazer. $O$ fato de as crianças serem sírias, e a menção de que seus pais faziam parte do grupo e estavam com elas, implica que essas pessoas eram igualmente sírias. Não há nada de errado de pessoas sírias irem para a Áustria, mas as condições em que elas foram encontradas, e o contexto no qual essas informações estão sendo apresentadas no texto, permitem inferir, também reforçando as hipóteses acima levantadas, de que se trata de migrantes que estão fugindo de seu país de origem e entrando de forma escusa em outro.

A informação de que a Áustria fica na Europa, informação que igualmente faz parte do conjunto de informações velhas, o fato de que a Europa não quer mais receber os migrantes, reforça a suposição de que as pessoas estavam escondidas. O outro input visual/lexical, o termo 'lotado', igualmente traz suposições a respeito da situação em que se encontravam aquelas pessoas e, obviamente, as crianças. Assim, pelas pistas decodificadas e pelas inferências realizadas, a ambiguidade do subtítulo se desfaz no sentido de que não apenas as crianças estavam em estado precário, mas os pais também. No segundo parágrafo, ajusta-se o significado de alguns verbos, como 'desaparecer', 'sumir' e 'deixar' (o hospital). Algumas hipóteses podem ser canceladas, por exemplo, as crianças não foram sequestradas; por outro input visual, a saber, as idades das crianças, é igualmente possível cancelar a suposição de que elas tenham decidido fugir - ao menos enfraquecê-la bastante.

Além disso, passa a ficar mais fortemente manifesta a suposição de que os pais também foram levados ao hospital e tratados, pois, pela informação, as crianças desapareceram com os pais. Como é possível observar, há uma espécie de flutuação na manifestabilidade das suposições; elas vão surgindo, 
ficando mais fortes ou mais fracas, a ponto de serem, inclusive, descartadas, conforme o texto avança. Essa análise é muito breve, e, mesmo assim, caso todos esses aspectos tivessem sido codificados, percebemos problemas de rapidez e economia na troca comunicacional, especialmente da natureza do texto jornalístico impresso. Tudo o que pode ser deixado para ser recuperado pelo leitor pode sê-lo - contanto que se ofereçam os inputs mais relevantes.

Vejamos mais um caso de clara quebra a máxima griceana da quantidade, mas agora não mais em antetítulo, títulos e subtítulos, que, geralmente têm essa natureza de, resumidamente, orientar o leitor para ler o que completaria aquelas informações.

(2) Três crianças sírias hospitalizadas por desidratação severa depois de serem encontradas na Áustria em um caminhão lotado de imigrantes.

No trecho, além da quebra da máxima griceana da quantidade, vemos igualmente uma quebra da máxima de modo, especialmenteno que diz respeitoà ordem em que os fatos ocorreram: primeiro fala-se que elas foram hospitalizadas, depois da desidratação, depois do fato de serem sido encontradas. A ordem dos fatos é outra. Pela TR, essas pistas, contudo, são relevantes o suficiente para trazerem à memória do leitor uma série de suposições, ele pode reconstruir inclusive uma série de eventos e supor detalhes a respeito do ocorrido.

Nesse sentido, muitas suposições, embora fracamente implicadas, são importantes para a compreensão da relação entre ser encontrado em um caminhão e estar desidratado. As inferências podem ser avaliadas a partir de aspectos como validade, adequação e relevância. É somente a partir desse enriquecimento inferencial que se pode encontrar sentido, uma vez que não há relação direta entre estar desidratado e ser encontrado em um caminhão lotado de imigrantes. Inúmeros aspectos que não precisam ser codificados podem ser deixados para o leitor inferir, bastando, por parte do emissor, dar as pistas certas e o receptor lançar mão das suposições armazenadas na sua memória enciclopédica. O leitor não irá, por exemplo, inferir, ou estaria não sendo relevante, ou seja, fazendo um esforço de processamento muito maior do que o necessário, que as crianças estão desidratadas por estarem na Áustria ou só por estarem em um caminhão.

Através dessa notícia, não apenas acrescentam-se novas informações sobre o que ocorreu com aquelas crianças, mas ao que acontece com os migrantes em situação de refugiados. Em outras palavras, enquanto informação nova, as suposições tornadas mutuamente manifestas, só que agora sobre crianças, em um contexto já de muitas tragédias, é uma forma de não apenas acrescentar 
mais suposições para o ambiente cognitivo do leitor, mas elas podem também reforçar as suposições de que a situação de migrantes que fogem das guerras e tentam entrar na Europa está mais e mais difícil.

É claro que existem opiniões e opiniões escusas, escondidas nos textos. Contudo, o fato de, pela TR, ser possível explicar como a comunicação falha tal aspecto pode ser explicado. Isso ocorre quando o leitor não captura uma intenção comunicativa ou quando atribui uma intenção ao emissor sem que ela de fato tenha sido expressa. Mais uma vez, tornam-se fundamentais as noções de implicaturas fortes e fracas: "quão mais forte a comunicação de uma suposição, maior a responsabilidade do emissor na determinação do conteúdo veiculado; quão mais fraca a comunicação, maior a responsabilidade do receptor na identificação do conteúdo apreendido" (Sartori, 2015, p. 413).

A relevância de um input não está no input sozinho, nem na cognição do indivíduo sozinha, mas justamente na interface estímulo/cognição (Dias, 2010). Assim, dado que as intuições de relevância são relativas a contextos, uma suposição pode ser mais relevante num contexto do que em outro. Não há como controlar exatamente o contexto, afinal, ele é responsabilidade do receptor, o que o emissor só pode fazer supor qual o contexto que o ouvinte deveria/ poderia construir para interpretar algo conforme a sua intenção comunicativa e escolher os melhores inputs para tanto.

As suposições são consideradas como fortemente implicadas, claramente pretendidas pele emissor; (ii) fracamente implicadas, certamente menos pretendidas pelo emissor, e mais da responsabilidade do receptor; e as não comunicadas através do enunciado por serem exclusivamente mais da responsabilidade do receptor: quão mais fracas as implicaturas, mais da responsabilidade do ouvinte elas são (Sperber; Wilson, 1995). Por exemplo, pode ser que um leitor infira que emissor está fazendo uma crítica à segurança e qualidade dos hospitais na Áustria. Essa inferência é muito mais de responsabilidade do leitor do que do emissor, muito embora tenha a ver com a notícia, ela tenhasidoconstruída a partir doselementose inputs da próprianotícia.

A abordagem que agora envolve aspectos lógico/cognitivos permitiu explicar por que e como tantos aspectos do texto, mesmo não sendo codificados, podem ser tomados como fazendo parte do texto, tornando-o plausível, lógico, etc. - com todas as propriedades, ao menos com as mínimas necessárias, para que se possa aceitá-lo como sendo jornalístico, informativo, verdadeiro e relevante. Um aspecto muito importante e ressaltado por vários teóricos que vêm se dedicado a esse tipo de investigação pragmática consiste no aceite do ajuste on-line das interpretações. Como vimos, algumas suposições, embora geradas, acabaram sendo até canceladas, isso se deve, segundo Sperber eWilson 
(1995), ao fato de que o conceito comunicado pelo uso de uma palavra pode ser diferente do conceito codificado por ela. Há, portanto, ajustes - e desde Grice - sabe-se e modela-se isso. Dado que se está na interface com a comunicação, o cancelamento e ajuste podem ser rápidos e eficientemente providenciados.

\section{Conclusão}

Ao caracterizar a natureza da significação complexa em linguagem natural, em uma abordagem de interfaces externas, comunicação, cognição e lógica, e internas, semântica e pragmática, à luz da metateoria das interfaces, em contextos comunicativo-sociais, foi possível demonstrar e defender que a presença de implícitos em textos jornalísticos do gênero informativo não caracteriza necessariamente a veiculação escusa de conteúdos opinativos. Vimos que não somente é possível, mas é preciso diferenciar tipos de implícitos e que, uma coisa é o fenômeno, outra é o uso que se faz dele, aspecto esse que, sim, pode ser fonte de propriedades opinativas.

Mostramos que a significação implícita, capturada por processos inferenciais, não necessariamente constitui a editorialização do gênero informativo - embora tal fenômeno seja, paradoxalmente, um dos melhores recursos para tanto. Na verdade, esse recurso tem um papel importante na riqueza informacional e na constituição de uma textualidade eficiente dos textos. Destacamos a importância desses implícitos no que se refere à economia que eles oferecem à codificação do texto propriamente dito e à não necessidade de que o leitor tenha que decodificar e processar informações relativamente redundantes. Por fim, mostramos que a identificação de propriedades opinativas pode ser explicada não pelo texto, mas pela atribuição de intenções por parte do leitor. Há inúmeros outros aspectos interessantíssimos a serem explorados, como o papel das emoções na interpretação, entre outros.

\section{Referências}

ASSIS, Francisco de. Fundamentos para a compreensão dos gêneros jornalísticos. Revista ALCEU. Rio de Janeiro. v. 11, n. 21, p. 16-33, jul./dez. 2010. Disponível em http://revistaalceu.com.puc-rio.br/media/Alceu21 2.pdf. Acesso em: 15 ago. 2016.

BAHIA, Juarez. Jornal: história e técnica. 4. ed. São Paulo: Ática, 1990.

CAMPOS. Jorge. Leitura, cognição e inferência. IN: PEREIRA, Vera Wannmacher; SILVA, Aline. (et al.). Leitura e cognição: teoria e prática nos anos finais do ensino fundamental. Porto Alegre: EDIPUCRS, 2009. 
CHAPARRO, Manuel Carlos. Pragmática no jornalismo: buscas práticas para uma teoria da ação jornalística. São Paulo: Summus, 1994.

COSTA, Jorge Campos da. A relevância da pragmática na pragmática da relevância. Porto Alegre, 1984. 188 p. Dissertação (Mestrado), Instituto de Letras e Artes, Pontifícia Universidade Católica do Rio Grande do Sul, 1984.

COSTA, Jorge Campos da. Ciências da linguagem: comunicação, cognição e computação. In: AUDY, Jorge Luis Nicolas; MOROSINI, Marília Costa (Orgs.). Inovação e interdisciplinaridade na universidade. Porto Alegre: EDIPUCRS, 2007, p. 345-376.

Diálogos: questões interdisciplinares. In: FIGUEIREDO, Débora de Carvalho et. at. (Orgs.). Sociedade, Cognição e Linguagem: apresentações do IX CELSUL, 2012. p. 149-169.

A retórica inferencial do discurso político. Disponível em: http://www. jcamposc.com.br/textos disciplinas/aretoricainferencialdodiscursopolitico. pdf. Acesso em: 24 jul. 2016.

DIAS, Stéphane Rodrigues. $\mathbf{O}$ processo inferencial na interface texto/imagem. In: Encontro do CELSUL, 2010, Palhoça. Anais do IX Encontro do Celsul. Disponível em: $\quad$ http://www.celsul.org.br/Encontros/09/artigos/Stephane\%20Dias.pdf. Acesso em: 15 jul. 2016.

DOUGLAS, Joaquim. Jornalismo: a técnica do título. Rio de Janeiro: Agir, 1966.

GRICE, Paul. Logic and conversation. In.: GRICE, Paul, Studies in the way of words. New York: Harvard University, 1991, p. 22-40.

HICKS, Wynford. English for journalists. New York: Routledge, 1998.

KEEBLE, Richard. The newspapers handbook. New York: Routledge, 2001.

KUNCZIK, Michael. Conceitos de jornalismo: norte e sul. 2. ed. São Paulo: EDUSP, 2002.

LEVINSON, Stephen C. Pragmatics. New York: Cambridge, 1983.

LEVINSON, Stephen C. Presumptive Meanings: the theory of generalized conversational implicature. Cambridge: MIT Press, 2000.

LUSTOSA, Elcias. O texto da notícia. Brasília: Editora UnB, 1996.

MARQUES DE MELO, José. Jornalismo opinativo: gêneros opinativos no jornalismo brasileiro. 3. ed. Campos do Jordão: Mantiqueira, 2003.

MARQUES DE MELO, José. Gêneros jornalísticos: conhecimento brasileiro. In: MARQUES DE MELO, José; ASSIS, Francisco de (Orgs). Gêneros jornalísticos no Brasil. São Paulo: UMESP, 2011, p. 23-42. 
MARTINS, Eduardo. Manual de redação e estilo de O Estado de S. Paulo. 3. ed. São Paulo: O Estado de S. Paulo, 1997.

MENNA BARRETO, Fernanda. As implicaturas conversacionais generalizadas na interface entre a semântica e a pragmática. 2003. 159 f. Dissertação (Mestrado em Linguística) Faculdade de Letras, PUCRS, Porto Alegre, 2003.

PEUCER, Tobias. Os relatos jornalísticos. Comunicação \& Sociedade: Revista do Programa de Pós-Graduação em Comunicação Social da Universidade Metodista de São Paulo, São Bernardo do Campo: ano 22, n. 33, p. 199-214, $1^{\circ}$ sem. 2000. Disponível em: http://revistas.univerciencia.org/index.php/estudos/article/ viewFile/5958/5427. Acesso em: 26 jul. 2016.

SARTORI, Roberta. A relevância da inferência relevante: uma abordagem da significação implícita via teoria das implicaturas. 1999. 160 f. Dissertação (Mestrado em Linguística) Faculdade de Letras, PUCRS, Porto Alegre, 1999.

SARTORI, Roberta. 0 mundo dos implícitos no debate político-jurídico da eleição presidencial norte-americana de $\mathbf{2 0 0 0}$ através do discurso jornalístico: uma abordagem pragmático-lógico-cognitiva da inferência na interface com a comunicação. 2015. 548 f. Tese (Doutorado em Linguística). Faculdade de Letras, PUCRS, Porto Alegre, 2015.

SHANNON, Claude Elwood; \& WEAVER, Warren. The Mathematical Theory of Communication. Urbana: University of Illinois Press, 1949.

SILVEIRA, Jane Rita Caetano da; FELTES, Heloísa Pedroso de Moraes. Pragmática e cognição: a textualidade pela relevância. Porto Alegre: EDIPUCRS, 2002.

SPERBER, Dan; WILSON, Deidre. Relevance: communication and cognition. Harvard University Press. Cambridge: Massaschusetts, 1995.

SUZUKI, Anik Ferreira. A herança lítero-jornalística da reportagem impressa para o próximo milênio. In: HAUSSEN, Doris Fagundes (org.). Mídia, imagem e cultura. Porto Alegre: EDIPUCRS, 1999, p. 59-76.

Recebido em: 23/9/2016

Aceito em: 16/11/2016

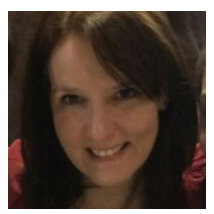

Endereço da autora

Roberta Sartori Luso de Carvalho <rsartori@espm.br>

Escola Superior de Propaganda e Marketing - Sul

Rua Guilherme Schell, 268 - Bairro Santo Antônio

90640-040 - Porto Alegre (RS) - Brasil 